\title{
An Overview on the Development of Internal Control in Public Sector Entities: Evidence from Kosovo
}

\author{
Submitted 20/08/19, 1st revision 12/09/19, 2nd revision 22/10/19, accepted 10/11/19
}

\begin{abstract}
Sead Ujkani ${ }^{1}$, Nexhmie Berisha Vokshi ${ }^{2}$
Abstract:

Purpose: The development and implementation of Public Internal Financial Control (PIFC) in the management processes plays an important role in providing sound financial management, transparency, efficiency and effectiveness in the public sector entities.

Design/Methodology/Approach: In this paper we have analysed the annual reports on the functioning of the PIFC system in the public sector of Kosovo for the 2014 - 2017 period. The analysis has been completed even more, based on the annual reports of National Audit Office, progress reports published by the European Commission, showing the progress achieved under the EU directives as well as the data from the monitoring reports of SIGMA (Support for Improvement in Governance and Management).

Findings: The findings show that the implementation of rules and procedures for internal control in budget organizations lags behind the development of the overall framework. Practical Implications: Continuous improvements in the field of Public Internal Financial Control are important steps in the process of European integration, while Kosovo has made considerable efforts to develop the control environment and implement the PIFC principles, particularly by establishing the appropriate legal, and institutional framework to support the PIFC system.

Originality/Value: PIFC development is a continuous process and is part of the public administration reform, hence this paper contributes in identifying possible gaps and weaknesses in the system of internal control in Kosovo and provides recommendations for their improvement.
\end{abstract}

Keywords: Internal control, public sector, public sector entity, control environment, risk assessment, control activities, information and communication, monitoring.

JEL Classification: M42, M48, H83, P35.

Paper Type. Research article.

\footnotetext{
${ }^{l}$ Faculty of Economics, University of Prishtina, Kosovo, sead.ujkani@uni-pr.edu

${ }^{2}$ Associate Professor, PhD, Faculty of Economic, University of Prishtina, Kosovo, nexhmie.berisha@uni-pr.edu
} 


\section{Introduction}

Effective public sector governance encourages better decision-making and efficient use of resources, which at the same time strengthens the responsibility for managing these resources (IFAC \& CIPFA, 2013). Pickett, (2011) argues that good governance is dependent on a management that understands the risks it faces and is able to maintain control of the organization. According to the international framework good governance in the public sector, the function of good governance in the public sector is to ensure that entities achieve their intended outcomes while acting in the public interest at all times and among others it also requires effective arrangements for managing risks and performance through robust internal control and strong public financial management as well as implement good practices in transparency, reporting, and audit, to deliver effective accountability (IFAC \& CIPFA, 2013). Good governance includes clearly articulated ethical values, objectives, and strategies, appropriate tone at the top, and internal control (Goodson, Mory \& Lapointe, 2012).

The internal control system has always been and still continues to be the basis for an effective governance of the organization, while its importance gained great attention at the beginning of the 21 st century following a series of scandals, and failures of various economic entities. The weaknesses identified in the internal control systems have contributed to increasing demands for improved governance of organizations, risk management and internal control. In response, new laws, regulations, and standards have been prepared and implemented in practice focusing on managerial accountability and compliance with applicable laws and regulations. Regulators and other stakeholders have higher expectations regarding governance oversight, risk management and fraud prevention. These events have led to a move towards more robust compliance at a global level, which will require much more improvements in internal controls and will change the nature of governance fundamentally.

Berisha-Vokshi (2015) notes that internal control is one of the most important and fundamental concepts, which includes all processes aimed at successful development of the operation, always regarding achieving objectives, eliminating obstacles and avoiding ascertained violations by taking the necessary measures against them.

Internal control represents an area of interest for all users of financial statements, as well as for the external auditor when providing conclusive audit evidences, necessary to underlie the audit opinion (Briciu, Dănescu, Dănescu, \& Prozan, 2014), hence, internal control remains an important topic in business and organisational life, for the investors, legislators and as well as the supervisory authorities that enforce them (Arwinge, 2013). According to (SIGMA, 2018), the objectives of internal control are to ensure that there is:

- A managerial structure capable of delivering the objectives of the organization; 
- A strategic planning process linking organisational objectives to the government's overall vision;

- Operational planning linking operational objectives to budgetary, personnel and other resource requirements;

- A system of controls to prevent losses arising from misuse of or damage to the assets and other resources of the organisation;

- Communication leading to accurate, relevant and timely information about the organisation's financial and operational performance;

- A monitoring and reporting process showing the level of achievement towards objectives linked to resource utilisation.

\section{Literature Review}

Internal control system is an important component for quality management of organizations, which incorporates ongoing tasks and activities, carried out by people, and provides reasonable assurance that the objectives of an organization will be achieved. Such a characteristic is also specified in defining the concept of internal control published by the COSO framework: Internal control is a process, effected by entity's board of directors, management, and other personnel, designed to provide reasonable assurance regarding the achievement of objectives relating to operations, reporting, and compliance (COSO, 1992). The Framework (COSO, 1992) defines the internal control objectives in three categories as follows:

- Reliability of financial reporting;

- Effectiveness and efficiency of operations;

- Compliance with applicable laws and regulations.

Whereas, (INTOSAI, 2016) in the definition of internal control, in addition to the objectives set out in the definition of the COSO framework, includes as a specific objective of internal control, safeguarding resources against loss, misuse and damage. Determining such an objective places internal control as the first line of defence in safeguarding resources.

According to Moeller (2013) we should think of internal controls not as just one solitary activity but as a series of related internal system actions. Therefore, internal control refers to a set of defined activities included in a program with purpose of identifying and monitoring various events that may result in a significant error, omission, erroneous statement or fraud, and thus affect the organization's management and achievement of its objectives. Internal control is not oriented only to the implementation of a particular model or procedure and according to Hightower (2009) an internal controls program is the core where governance, risk, oversight, documentation, and assessment come together. Internal control enjoys a unique role to assist the organization in achieving its objectives and is considered as a key mechanism of organizational governance. 
Power, (2007) argues that internal control systems now stand at the centre of government thinking and practice, while their designed principles are now global and are part of public policies, laws, and codes of organizational governance. This is also supported by (Palfi \& Muresan, 2009) that emphasize that strong internal control, including internal and external auditing, are part of a sound organizational governance. A good control system encourages accountability in resource management, efficient operations, less risk-taking, greater compliance with laws, regulations, policies, and procedures, and greater ability to eliminate fraud and abuse (Altamuro \& Beatty, 2010; Feng, Li and McVay, 2009).

Having effective internal control system can strengthen the organization's process, structure and value in the increasing oversight, reducing and preventing misuse such as fraud and asset misuse (Zakaria, Nawawi \& Puteh Salin, 2016). There is a direct relationship between the general objectives, which represent what an entity strives to achieve, and the internal control components, which represent what is needed to achieve the general objectives (INTOSAI, 2016). Feng et al. (2009) note that internal control quality has an economically significant effect on internal management reports and thus decisions based on these figures.

Internal control systems have long been advocated as a mechanism for establishing high quality financial reporting, and organizations have voluntarily used them for this purpose (Altamuro \& Beatty, 2010). This is also confirmed by Ramdany (2015) who states that effectiveness of internal controls have a significant effect on the financial reporting quality which serves to provide a basis for managerial decisionmaking. Arens, Randal \& Beasley (2012) emphasize that weak internal controls will lead to serious misstatements of financial statements. A global survey conducted by the International Federation of Accountants on Risk Management and Internal Control, among others concluded that internal control systems should be integrated into the governance, strategy and overall organizational operations (IFAC, 2011).

A very important aspect of the internal control system belongs to the part of the public internal financial that refer to the government's internal control systems aimed at protecting the financial interests of the government at large (Koning, 2007). This is meant as a whole of the managerial, financial and other systems, including administrative structure procedures as well as internal auditing, with a view to the transparent and legal implementation of the management objectives (BerishaVokshi, 2015). Koning (2007) analyses the PIFC concept as follows:

- Control: meaning all activities to oversee the entire field of financial management, enabling the government to be "in control" of its finances;

- Internal: covering controls exercised by central and decentralised government agencies;

- Financial: stressing the character (whether administrative, managerial or budgetary) of the activities to be checked;

- Public: meaning covering all activities in the public sector. 
PIFC is a comprehensive concept that is very important to support the candidate country towards European integration, helping to improve internal control systems. The notion of PIFC according to Koning (2007) can be expressed as follows:

$$
\mathrm{PI} f \mathrm{C}=\mathrm{IC}+\mathrm{CHU} \text {, where IC stands for }(\mathrm{FMC}+\mathrm{IA})
$$

Based on the expression mentioned above, the country should focus on developing the following three elements:

- The financial management and control (FMC) systems;

- A functionally independent internal audit (IA);

- Central Harmonisation Unit (CHU) - a centralised organisation responsible for harmonising and coordinating the establishment, implementation and improvement of FMC and IA (Koning, 2007).

The implementation of an effective internal financial control system (PIFC) requires commitment to effective management, personal integrity and professionalism among senior management at all levels (Principles of PIC, 2015; The world of PIFC, 2006). The key practical elements of such a system can be described as follows (SIGMA, 2004):

- The system should be based on the rule of law;

- Sound financial management systems should be in place;

- Effective control activities and procedures should be implemented;

- Effective internal audit functions should be in place at relevant levels;

- Mechanisms for the fight against fraud and corruption should exist;

- A strong external oversight by parliament and an effective public sector external audit.

\section{Public Internal Financial Control in Kosovo}

PIFC has been implemented in Kosovo since 2005, as a part of the state consolidation process to ensure proper control of public resources management and at the same time, an indispensable element in Kosovo's path towards the European Union. The implementation of robust internal control systems is in the interest of all EU taxpayers, so the successful implementation of PIFC is decisive to provide reasonable assurance that public resources are used effectively and economically, being at the same time integral, and a vital part of the governing system in Kosovo.

Since the beginning of implementation, Kosovo has made considerable efforts to develop the control environment to implement the principles of PIFC. Significant progress has been made in this regard, based on PIFC policy papers, and EU good practices. Significant progress has been made in the preparation of legislation, regulations and procedures for the implementation of integrated accounting and budgetary controls, which has enabled the orientation for implementation of 
integrated controls over public funds and resources (Law no. 06/L-021, 2018; PIFC Policy Paper, 2011; PIFC Strategy, 2015).

Generally, the commitments made, including the drafting of the PIFC Strategy 2015-2019, have had a key objective improving the adequacy and efficiency of the financial management and control system in order to protect the public resources and to ensure that public funds are used to provide better public service in Kosovo. Another factor that has influenced Kosovo's focus on the full implementation of the PIFC framework and continued engagement for further development of control implementation in line with the internationally recognized framework and EU good practices have been the obligations that stem from the Financial Control Chapter of Article 97 of the SAA, which requires the cooperation between the parties to focus on priority areas related to the EU acquis in the field of public internal financial control (SAA Kosovo-EU, 2015) .

\subsection{Legal and Institutional Framework}

Kosovo has made significant progress in preparing the proper legal framework related to PIFC and the institutions for its implementation. In general, the main laws, regulations and procedures required for PIFC implementation exist, while some others documents are in the finalization process, taking into account the need for harmonization of secondary legislation with the new approved law. The existing PIFC legal framework contains general principles and refers to universally accepted standards. In April 2018 the Law on Internal Control of Public Finances came into force (Law no. 06/L-021, 2018), which regulates the internal control system of public finances, including financial management and control, internal audit, and their harmonization, in accordance with international standards for internal control and internal audit. The following is an overview of the basic documents that enable the functioning of PIFC in Kosovo.

Figure 1. Regulatory framework

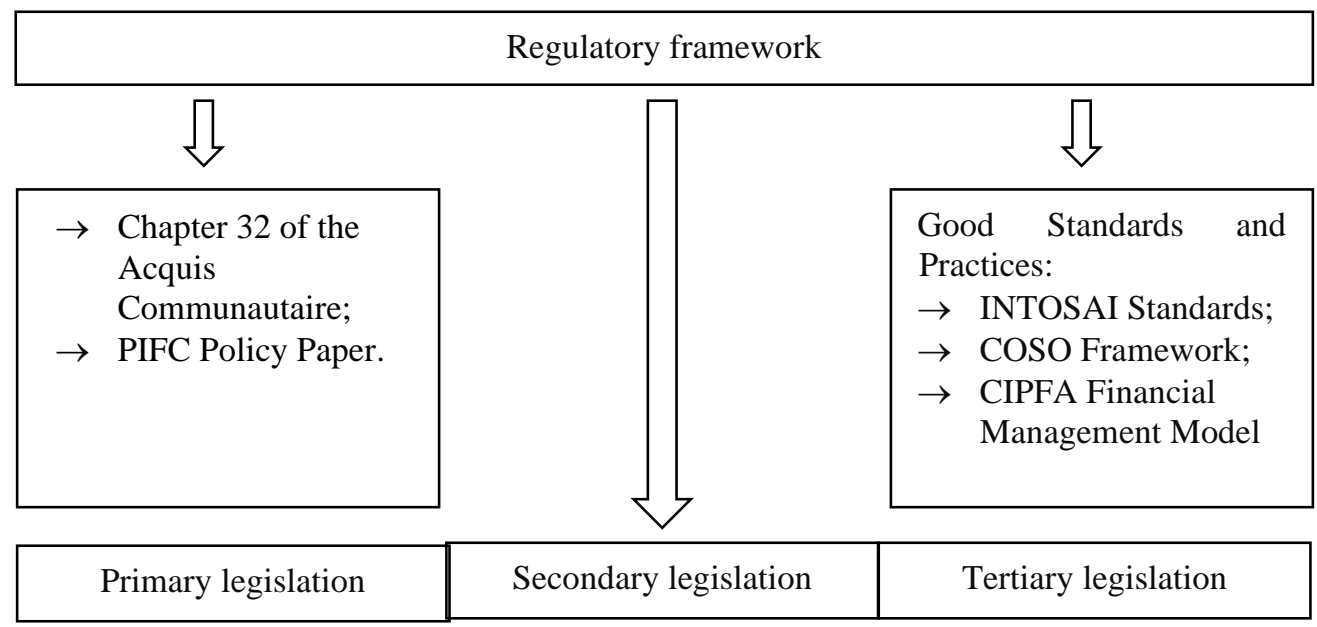




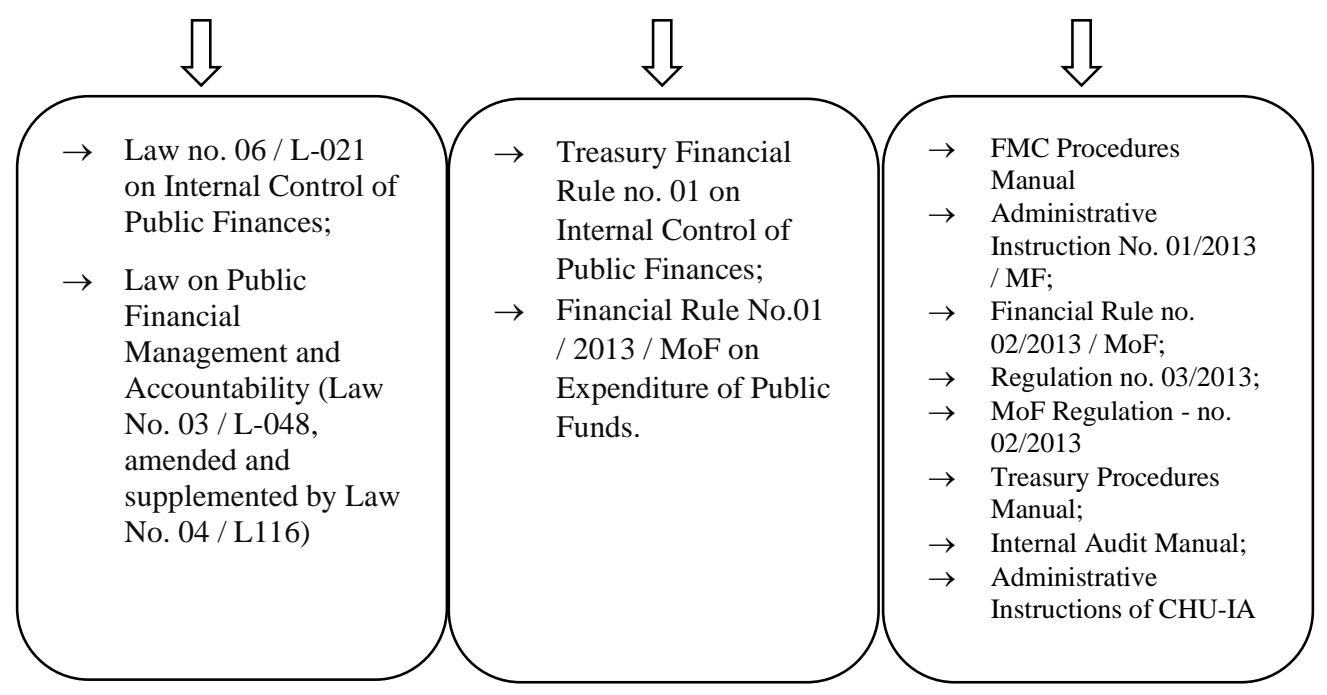

Source: Authors.

Based on the requirements of the Law on Internal Control of Public Finances (Law no. 06/L-021, 2018), the Minister of Finance is responsible for coordinating and harmonizing the PIFC system for all entities of the public sector. At the same time, to strengthen the implementation of the internal control system and to establish an accountability chain in accordance with PIFC requirements. Accountability consists of a chain of participants where each is responsible for achieving certain goals, and are held accountable to a higher level authority to achieve these goals. The highest level of authority in this chain is held by who are represented by elected members in the Assembly and in municipal governments (PIFC Policy Paper, 2011).

Figure 2. Chain of FMC accountability for Central Budget Organizations

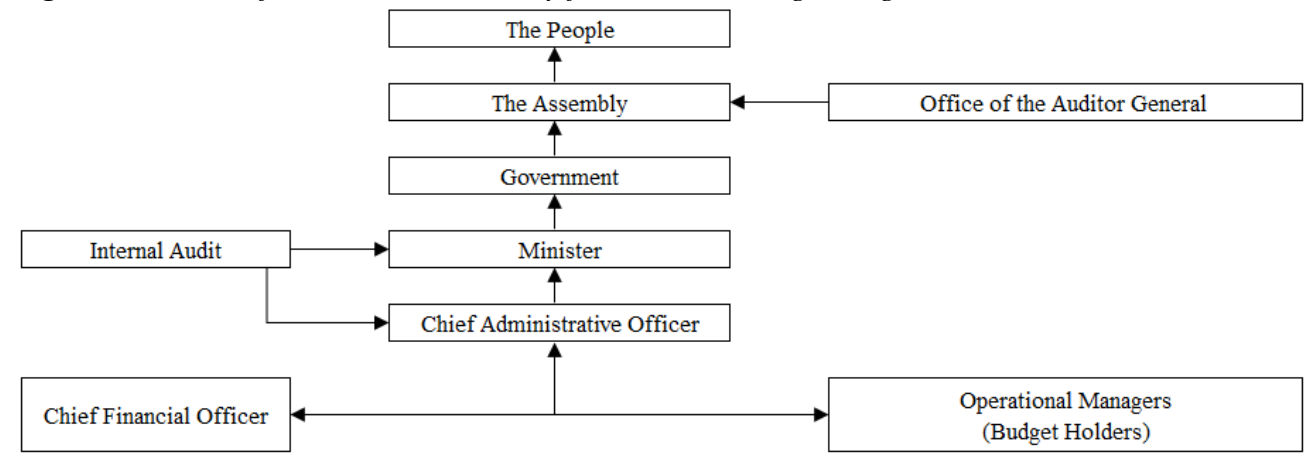

Source: Fundamentals of Financial Management and Control (MoF RKs, 2016).

For municipal governments, the mayor is elected by the people and is therefore accountable to the people. This is demonstrated in the figure below. 
Figure 3. Chain of FMC accountability for municipalities

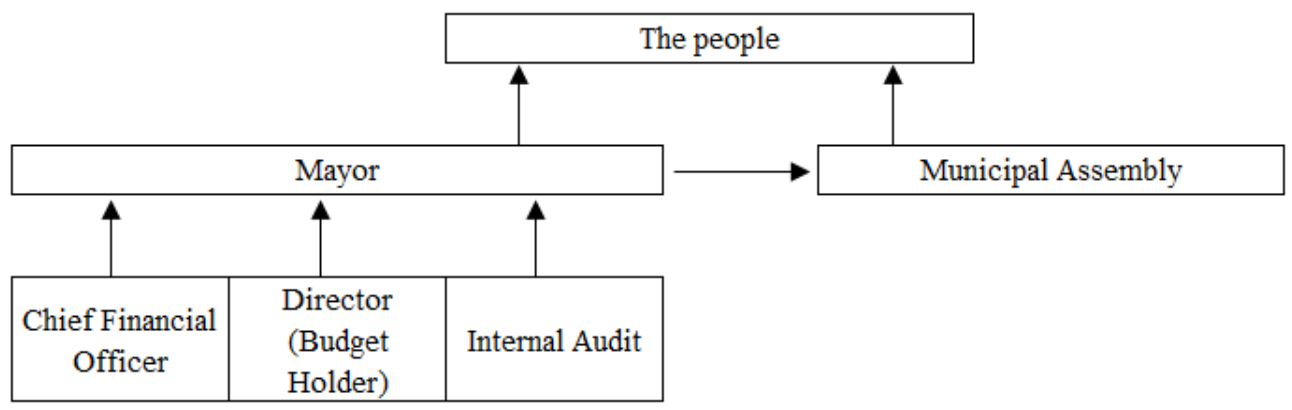

Source: Fundamentals of Financial Management and Control (MoF RKs, 2016).

\section{Analysis of the Current Situation}

\subsection{Methodology}

The internal control procedure applies to all budget organizations in Kosovo. Controls range from one organization to another, depending on the type of activity, size, volume of transactions and risks in the process of meeting objectives (BerishaVokshi, 2015). Kosovo has made significant progress towards establishing the legal and institutional framework for PIFC support, setting the basic administrative prerequisites to improve financial management accountability. At the same time, with the aim of functioning and harmonizing internal control processes in accordance with EU standards and practices, various projects have been carried out in order to facilitate the process of public administration reform, thus improving the public finance management and accountability.

However, despite major improvements, the internal control system is still not at a satisfactory level and delays in the full implementation of the recommendations affect the repetition of weaknesses and deficiencies of control, and there is a long way to go before it can be considered as an integral part of the management of governmental activities in Kosovo.

To present the level of internal control of public finances in public sector entities in Kosovo and its use in budget organizations we have analysed the annual reports on the functioning of the Public Internal Financial Control (PIFC) system in the public sector of Kosovo for the 2014 - 2017 period. These reports reflect the assessments made by Public Sector Entities (PSE) 3 in the field of Public Internal Financial Control (PIFC) and include full information, including statistics and the state of implementation of internal control in public sector organizations. The information is provided by a self-assessment questionnaire on the progress in the implementation of internal control, which is compliant with the legal requirements each year by budget organizations. The analysis has been completed even more, based on the annual

\footnotetext{
${ }^{3}$ Completion of the survey is mandatory for budget organisations.
} 
reports of the Auditor General, progress reports published by the European Commission, showing the progress achieved under the EU directives as well as the data from the monitoring reports of $\mathrm{SIGMA}^{4}$.

The questionnaires ${ }^{5}$, based on the annual report on the functioning of the Public Internal Financial Control (PIFC) system in the public sector of Kosovo, consist of five sections corresponding to the five components under the COSO framework and INTOSAI international standards, and include the principles ${ }^{6}$ that represent the fundamental concepts associated with each component. Whereas, the assessment of the functioning of internal control according to the answers given is done as follows:

- The three-point assessment shows that this aspect of internal control is understood and works well across all structures of budget organizations;

- The two-point assessment - indicates that this aspect of internal control is partially understood and works;

- The one-point assessment - indicates that this aspect of internal control is not yet applied and / or is not understood.

Based on data from the annual reports on the functioning of the Public Internal Financial Control System (PIFC) in the public sector of Kosovo for the $2014-2017$ period (refer to Table 1), we note that the assessment of questions has been overestimated by managers, which in many cases has come as a result of low awareness of the importance of internal control functioning. However, the assessment gradually has taken its form of sustainability, providing a more realistic overview of the level of implementation of public internal financial control in public sector entities in Kosovo and identifying the challenges and deficiencies that accompany the development of PIFC.

\subsection{Analysis and Discussion}

The situation of the internal control components is presented below:

$\rightarrow \quad$ Control Environment - Control environment is a key component for the implementation of internal control and consists of a set of standards, processes, and structures that provide the basis for carrying out internal control across the

\footnotetext{
${ }^{4}$ SIGMA (Support for Improvement in Governance and Management) is a joint initiative of the OECD and the European Union. Its key objective is to strengthen the foundations for improved public governance, and hence support socio-economic development through building the capacities of the public sector, enhancing horizontal governance and improving the design and implementation of public administration reforms, including proper prioritisation, sequencing and budgeting. (http://www.sigmaweb.org)

${ }^{5}$ https://mf.rks-gov.net/desk/inc/media/499B8A09-D7A4-4A43-84F9-777387A5D224.pdf

${ }^{6}$ The COSO Framework sets out seventeen principles that represent the basic concepts pertaining to each component, while in Kosovo only thirteen are applied, which are analysed in the paper.
} 
organization (COSO, 1992). Understanding and proper implementation of the principles of the control environment component create the basic prerequisites of internal control in delivering better public services and ensuring value for the money given in the service delivery. As it is defined in the COSO Framework, the control environment comprises the integrity and ethical values of the organization; the parameters enabling the board of directors to carry out its governance oversight responsibilities; the organizational structure and assignment of authority and responsibility; the process for attracting, developing, and retaining competent individuals; and the rigor around performance measures, incentives, and rewards to drive accountability for performance (COSO, 1992).

By analysing the data for the control environment component, we notice that, in comparison to the other components, there is progress in general, but it should be noted that there is still a need for improvement of the control environment principles. In this component remains a priority, the improvement of effective accountability regarding governance oversight responsibilities in particular, as there is great stagnation ${ }^{7}$. While, as noted in the Annual Reports of the Auditor General and National Audit Office, progress reports and SIGMA monitoring reports, the senior management of the public sector entity should focus on drafting internal procedures, harmonizing strategic plans with the Medium Term Expenditure Framework and budget, drafting and monitoring action plans that should include timelines and persons responsible for their implementation.

Table 1. Functioning of PIFCS for Public Sector 2014-2017

\begin{tabular}{|c|c|c|c|c|}
\hline \multirow{2}{*}{ Components } & \multicolumn{4}{|c|}{$\begin{array}{c}\text { Year / Average of responses to the key areas in PIFC } \\
\text { questionnaires }\end{array}$} \\
\hline & 2014 & 2015 & 2016 & 2017 \\
\hline Control Environment & 2,72 & 2,54 & 2,62 & 2,57 \\
\hline Risk Assessment & 2,39 & 2,23 & 2,41 & 2,35 \\
\hline Control Activities & 2,67 & 2,49 & 2,59 & 2,57 \\
\hline $\begin{array}{l}\text { Information and } \\
\text { Communication }\end{array}$ & 2,81 & 2,66 & 2,72 & 2,68 \\
\hline Monitoring & 2,61 & 2,35 & 2,46 & 2,42 \\
\hline
\end{tabular}

Source: Annual Report of the CHU on Functioning of PIFCS for Public Sector 2014-2017

$\rightarrow \quad$ Risk Assessment - Risk assessment component is the most challenging part and in which upgrades are very much needed. According to COSO $(1992 ; 2004)$ framework, risk assessment is identifying and analyzing the risks relevant to achieve the objectives that form the basis for determining how to manage the risks. Risk

\footnotetext{
${ }^{7}$ According to the data from the annual reports on the functioning of the Public Internal
} Financial Control 2014-2017. 
assessment in budget organizations remains at an early stage and requires further support. The data analysed show a lack of progress in risk management, although most budget organizations have compiled a list of risks, but this list is not updated and monitored as required by FMC procedures. Also, many budget reallocations occur outside of the budget review process (Annual Audit Report '17, 2018; Kosovo Progress Report-EU, 2018; SIGMA, 2016). The risk assessment process, the process description and the establishment of controls in some budget organizations for high risk areas remain a major challenge for management. Some budget organizations have not yet identified, analysed, assessed and prepared a risk register. While some budget organizations lack a strategic plan, and for the preparation of risk registers, are based on the Medium Term Expenditure Framework. SIGMA's results show that the application of risk management is still at a low level (SIGMA, 2017).

$\rightarrow$ Control Activities - In the component of control activities there are significant improvements resulting from the advances made in the $\mathrm{KFMIS}^{8}$ program, electronic procurement and new changes supported by the Treasury and the Budget Department. According to the data analysis, priority should be given to the development of risk mitigation activities and especially the development of IT controls.

$\rightarrow \quad$ Information and Communication - In designing effective internal control within the organization, the key role is the availability of relevant and qualitative information, as required by the COSO framework. Information is necessary for the entity to carry out internal control responsibilities to support the achievement of its objectives (COSO, 1992). To improve the principles of information and communication, public sector entities should focus on the development of IT systems that provide relevant, reliable and up-to-date operational information from internal and external sources. In some PSEs there is a need for integration of various software applications to provide the most complete information. This is because the IT systems that are in use are not sufficiently linked, thus increasing the workload and the risk of error.

$\rightarrow \quad$ Monitoring - The most significant challenges facing budgetary organizations are: although there are various strategies drafted by BOs, they are not implemented or monitored to establish whether the objectives are being achieved (Annual Audit Report '17, 2018). Monitoring ensures that the internal control system is working as expected, and the goals and objectives of the organization are met (COSO, 1992), so in order to achieve this, much more work needs to be done to perform ongoing and/or separate evaluations to monitor whether the components of internal controls are present and functioning (Moeller, 2013).

\footnotetext{
${ }^{8}$ Kosovo Financial Management Information System.
} 
Figure 4. Functioning of the PIFC system in the public sectors

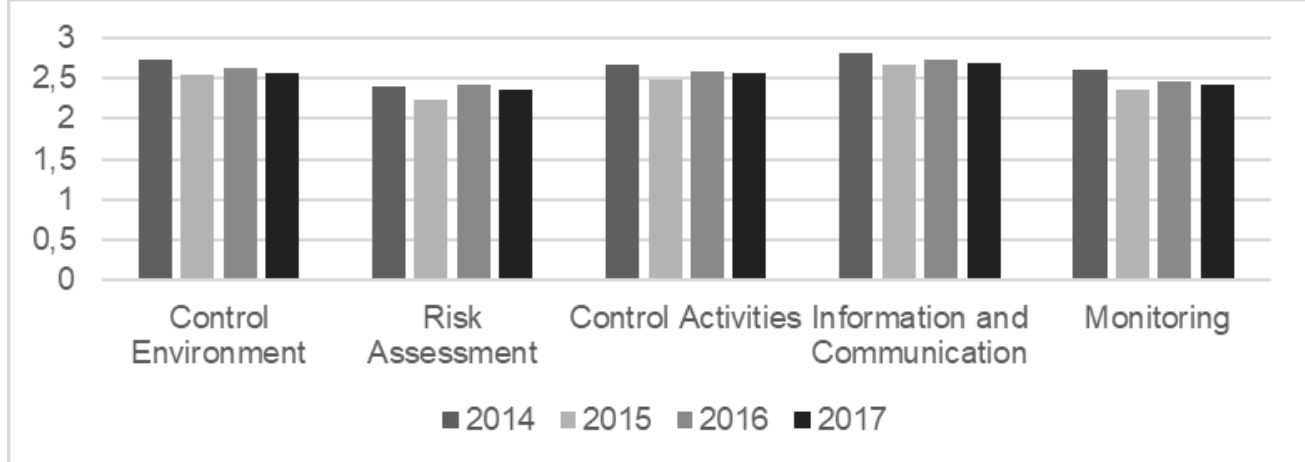

Source: Authors.

Based on the above data for each component, we note that the practical application of internal control still needs to be further developed, and this is confirmed by the Kosovo Progress Report-2018. The focus is mainly on the financial compliance of the annual budget execution, not so much with the strategic financial management, so according to (SIGMA, 2017) the implementation of rules and procedures for internal control in budget organizations lags behind the development of the overall framework. An important finding is that addressing the recommendations given have resulted in continued weaknesses in internal control. Based on data provided by the Annual Audit Report prepared by the National Audit Office (Annual Audit Report, 2015), weaknesses in internal control have reduced the effectiveness of budget organization activities, improper disclosure of information in the Financial Statements, as well as in certain cases with irregular payments.

One very important issue that has been highlighted is the lack of management and control systems for EU funds, as the European Commission currently undertake the tendering, contracting and payments required for all IPA-funded programs (SIGMA, 2016; 2017). To complete our analysis, we used the data from the SIGMA monitoring reports as well, which to support the European Commission's reinforced approach to public administration reform (PAR) in the European Union (EU) enlargement process developed the Principles of Public Administration ${ }^{9}$. Based on the aim of the paper, there is a proper reference for our analysis in Principles 6 and 7 in the area of public finance management in accordance with international standards, and the EU acquis.

Data for Principle No. 6 (SIGMA, 2017) argue that the overall framework for internal control is in place and the $\mathrm{CHU}$ has reported comprehensively on its implementation. Identified $\mathrm{s}$ deficiencies have come as a result of the delay in

\footnotetext{
${ }^{9}$ Principles define what good public governance entails in practice and outline the main requirements to be followed by during EU integration. Principles were developed in in 2014 and updated in 2017, with a new methodological framework developed to improve clarity, without changing the substance of the conceptual framework.
} 
implementing the Action Plan in accordance with the approved strategy. The Government has approved the conclusions in the annual report on PIFC implementation, but the process has stalled because no specific decision on corrective measures has been taken. This principle is measured through the 'Adequacy of the operational framework for internal control' indicator and its value is $3^{10}$. The following table presents monitoring data for sub-indicators, based on the criteria outlined in the Methodology Framework for Public Administration Principles (OECD/SIGMA, 2017).

Table 2. Adequacy of the operational framework for internal control

\begin{tabular}{|c|l|c|}
\hline \multicolumn{2}{|c|}{ Sub-indicators } & Points \\
\hline 1 & Policy for the development of internal control & $4 / 6$ \\
\hline 2 & Completeness of the regulatory framework for internal control & $5 / 5$ \\
\hline 3 & $\begin{array}{l}\text { Comprehensiveness and regularity of the annual review and reporting on } \\
\text { internal control }\end{array}$ & $3 / 5$ \\
\hline 4 & $\begin{array}{l}\text { Alignment between national budget management and control systems and } \\
\text { those for EU-funded programmes }\end{array}$ & $0 / 4$ \\
\hline \multicolumn{2}{|c|}{ Total: } & $12 / 20$ \\
\hline
\end{tabular}

Source: SIGMA Monitoring Report 2017.

Meanwhile, the data for Principle no. 7, suggest that the implementation of rules and procedures for internal control in budget organizations lags behind the development of the overall framework. In this regard, there is a good level of formal budget delegation to budget organization, supported by management information, but delegation of decision-making authority within central government organization is not widespread. Furthermore, key internal controls, such as risk management and procedures to report irregularities, are not yet common practice (SIGMA, 2016, 2017). Principle no.7 is measured through the "Functioning of internal control" indicator and its value is 2 , which also shows the obvious stagnation in applying internal control to the country's budget organizations. The relevant values for the monitoring sub-indicators for this principle are presented in Table 3 .

Table 3. Functioning of internal control

\begin{tabular}{|c|l|c|}
\hline \multicolumn{1}{|c|}{ Sub-indicators } & Points \\
\hline 1 & $\begin{array}{l}\text { Number of first-level budget organisations that are neither ministries nor } \\
\text { constitutional bodies }\end{array}$ & $1 / 3$ \\
\hline 2 & Alignment between organisational and budget structures $(\%)$ & $1 / 3$ \\
\hline 3 & $\begin{array}{l}\text { Credibility of controls for avoiding commitments above the expenditure } \\
\text { ceilings }\end{array}$ & $0 / 2$ \\
\hline
\end{tabular}

\footnotetext{
${ }^{10}$ The Analysis of Individual Principles is based on the indicators and monitoring subindicators outlined in the OECD (2017) Methodological Framework for the Principles of Public Administration, OECD Publishing, Paris, http: //sigmaweb.org / publications / Methodological-Framework-for-the-Principles-of-Administration-Public-November2017.pdf.
} 


\begin{tabular}{|c|c|c|}
\hline 4 & $\begin{array}{l}\text { Availability of reporting of total cost and physical progress of major } \\
\text { investment projects }\end{array}$ & $2 / 2$ \\
\hline 5 & $\begin{array}{l}\text { Effectiveness of basic managerial accountability mechanism for central } \\
\text { government bodies }\end{array}$ & $2 / 4$ \\
\hline 6 & Delegation of decision-making authority within ministries & $0 / 4$ \\
\hline 7 & Regularity and completeness of risk management practices & $3 / 3$ \\
\hline \multirow[t]{2}{*}{8} & Existence of reporting on irregularities & $0 / 2$ \\
\hline & Total: & $9 / 23$ \\
\hline
\end{tabular}

Source: SIGMA Monitoring Report 2017.

Based on analysis of relevant reports and objectives set out in the PIFC Strategy 2015-2019, the areas which need the attention and priority action are:

- To develop risk-based control environment;

- To improve efficiency, effectiveness, and economy of operations;

- To increase reliability of financial reporting;

- To do better planning and budgeting arrangements;

- To continue the introduction of the managerial accountability concept together with strengthening the culture of the delegation of responsibilities and authorities (PIFC Strategy, 2015).

\section{Summary and Conclusions}

Kosovo has made substantial progress towards establishing legal and institutional framework to support PIFC in providing a genuine platform for continuous development. In order for PIFC to be sustainable, it should be linked to public administration reforms. PIFC requires continuous development to achieve the essence of its implementation, so effective implementation of adopted strategies is the key to success. Budget organizations have shown signs that they are not fully responsible for policy and internal control in their sectors, and many planned activities have failed to apply as a result, the delay in adopting the new PIFC Law which has also conditioned the practical implementation of a significant number of proposed actions within the Public Internal Financial Control (PIFC) Strategy. Positive achievements have been noted in the process of advancing human capacity through the certification of internal auditors in budget organizations.

Further improvements in the field of public internal financial control should be considered as important steps in the process of approximation with the EU. A major challenge remains the failure to address recommendations given over the years, which have resulted in continued weaknesses in internal control and financial loss. To continue the development of PIFC, it is first necessary to harmonize the secondary legislation with the new approved law, then it is recommended to prioritize the implementation of the action plan for the PIFC strategy, and at the same time emphasize the monitoring process for meeting the planned objectives. 
Whereas, in order to improve the quality of financial information, it is recommended to continue further advancement and integration of information technologies systems used in budget organizations, as well as provide advisory activities and relevant trainings in budget organizations regarding the fulfillment of legal requirements of financial management and control. A very important part in this process is the further strengthen the objectivity and quality of financial management by BOs, in order to understand the potential offered by the self-assessment process in the development of good governance.

In conclusion, it is recommended that the role of the CHU should gradually change, from the development of PIFC to the practical implementation and monitoring of PIFC.

\section{References:}

Altamuro, J. \& Beatty, A. 2010. How does internal control regulation affect financial reporting? Journal of Accounting and Economics, 49(1-2), 58-74, https://doi.org/10.1016/j.jacceco.2009.07.002.

Annual reports on the functioning of the Public Internal Financial Control 2014-2017.

Annual Audit Report. 2015. Annual Audit Report 2015.

Annual Audit Report '17. 2018. Annual Audit Report 2017.

Arens, A., Randal, E. \& Beasley, M.S. 2012. Auditing and Assurance Services : An integrated Approach. Fourteenth Edition. https://doi.org/10.1108/01443570310496625.

Arwinge, O. 2013. Key Components of Internal Control. In Internal Control: A Study of Concept and Themes (pp. 37-53), https://doi.org/10.1007/978-3-7908-2882-5.

Berisha-Vokshi, N. 2015. Kontrolli i Brendshëm dhe Auditimi. Prishtina, Kosovo.

Briciu, S., Dănescu, A.C., Dănescu, T. \& Prozan, M. 2014. A Comparative Study of Wellestablished Internal Control Models. Procedia Economics and Finance, 15(14), 10151020, https://doi.org/10.1016/s2212-5671(14)00662-5.

COSO. 1992. Internal Control - Integrated Framework. COSO.

COSO. 2004. Enterprise Risk Management-Integrated Framework. Committee of Sponsoring Organizations of the Treadway Commission, https://doi.org/10.1504/IJISM.2007.013372.

European Commission. 2015. Principles of Public Internal Control, Position Paper No. 1 of Public Internal Control: An EU approach, Ref. 2015-1, http://ec.europa.eu/budget/pic/lib/docs/2015/CD02PrinciplesofPIC-PositionPaper.pdf.

Feng, M., Li, C. \& McVay, S. 2009. Internal control and management guidance. Journal of Accounting and Economics, 48(2-3), 190-209, https://doi.org/10.1016/j.jacceco.2009.09.004.

Goodson, S.G., Mory, K.J. \& Lapointe, J.R. 2012. Supplemental Guidance : The Role of Auditing in Supplemental Guidance: The Role of Auditing in Public Sector Governance. The Institute of Internal Auditors. Retrieved from www.globaliia.org/standards-guidance.

Hightower, R. 2009. Internal Controls Policies and Procedures. John Wiley \& Sons, Inc.

IFAC. 2011. Global survey on risk management and internal control. Professional Accountants in Business Committee. Retrieved from http://www.ifac.org/sites/default/files/publications/files/global-survey-on-riskmanag.pdf. 
IFAC \& CIPFA. 2013. Good Governance in the Public Sector-Consultation Draft for an International Framework, https://doi.org/10.1177/0095399713513140.

INTOSAI. 2016. Guidelines for Internal Control Standards for the Public Sector Gov 9100, 83, https://doi.org/10.1017/CBO9781107415324.004.

Koning, R. 2007. Public Internal Financial Control. Pristina, Kosovo.

Kosovo Progress Report-EU. 2018. Kosovo Report 2018.

Law no. 06/L-021. LIGJI Nr. 06/L-021 Për Për Kontrollin E Brendshëm Të Financave Publike. 2018.

Moeller, R.R. 2013. Executive's Guide to COSO Internal Controls. Executive's Guide to COSO Internal Controls, https://doi.org/10.1002/9781118691656.

MoF RKs. 2016. Bazat e Menaxhimit Financiar dhe Kontrolli. Retrieved from https://mf.rksgov.net/.

OECD/SIGMA. 2017. Methodological Framework for the Principles of Public Administration.

OECD/SIGMA. 2016. The Principles of Public Administration: A Framework for ENP Countries. OECD, Paris, http://sigmaweb.org/publications/Principles\%20-ENPEng.pdf.

Palfi, C. \& Muresan, M. 2009. Survey on Weaknesses of Banks Internal Control Systems. Pickett, S. 2011. The Essential Guide to Internal Auditing. Pristina, Kosovo.

PIFC Policy Paper. 2011. Government of Kosovo.

PIFC Strategy. 2015. Public Internal Financial Control Strategy 2015-2019.

Power, M. 2007. Organized Uncertainty: Designing a World of Risk Management. New York, Oxford University Press.

Ramdany. 2015. Influence The Quality of Accounting Information Systems and the Effectiveness of Internal Control on Financial Reporting Quality. Research Journal of Finance and Accounting.

SAA Kosovo-EU. 2015.

SIGMA. 2004. Internal Control Systems in Candidate Countries.

SIGMA. 2016. Monitoring Report 2016 - Kosovo.

SIGMA. 2017. Monitoring Report 2017 - Kosovo.

SIGMA. 2018. Managerial Accountability in the Western Balkans.

The world of PIFC. 2006. Welcome to the world of PIFC.

Zakaria, K.M., Nawawi, A. \& Puteh Salin, A.S.A. 2016. Internal controls and fraudempirical evidence from oil and gas company. Journal of Financial Crime, https://doi.org/10.1108/JFC-04-2016-0021 